\title{
Bullying entre pares na escola: desafio aos enfermeiros que atuam na atenção básica à saúde
}

\author{
Marta Angélica lossi Silva
}

${ }^{1}$ Enfermeira, Doutora em Enfermagem em Saúde Pública. Professora Associada da Escola de Enfermagem de Ribeirão Preto da Universidade de São Paulo. Ribeirão Preto, SP, Brasil. E-mail: maiossi@eerp.usp.br.

Não raramente nos deparamos com questionamentos acerca do papel e da pertinência do trabalho do enfermeiro frente à violência escolar. Estaria o enfermeiro preparado para tal? A violência escolar e sua abordagem seriam objeto do cuidado de enfermagem?

Para respondermos a estas questões, entre outros elementos é necessário contextualizarmos a enfermagem enquanto ciência e prática social capaz de dialogar com as necessidades dos sujeitos, seja no contexto individual ou coletivo. Essa enfermagem também capaz de estabelecer o cuidar numa abordagem epistemológica comprometida com a ética, com o verdadeiro encontro relacional entre quem cuida e quem é cuidado, com empoderamento e emancipação humana e evolução das sociedades ${ }^{(1-2)}$.

Portanto há que se considerar sua relação com a sociedade e, neste caso, com a violência em suas mais diversas tipologias e como problema de saúde pública. Ambas as relações se constituem, de fato, em premissas para que possamos agir sem ingenuidade: há uma estreita e íntima vinculação a ser estabelecida. No entanto, ainda percebemos uma lacuna, seja no campo prático, investigativo ou da formação, que viabiliza um agir e um compromisso do enfermeiro diante do quadro de violência cada vez mais frequente e presente no interior das escolas: a violência manifestada por meio de situações de bullying. Esta situação exige que a área da saúde, especialmente a enfermagem, estabeleça uma dimensão cuidadora na perspectiva da promoção à saúde individual e coletiva por meio da prática interdisciplinar e intersetorial.

Sendo assim, a partir de um trabalho articulado e conjugado na atenção básica em saúde, com as competências e especificidades de outras áreas, educação, assistência social, psicologia, referenciado pela promoção da saúde na escola, pelo cuidado integral e educação em saúde o enfermeiro pode estabelecer possibilidades de atuação conjunta na minimização e prevenção do bullying.

Nesse sentido, a atuação da enfermagem se estabelece na ação, na atitude e no envolvimento cotidiano da equipe e dos serviços, considerando a presença do "outro" no espaço assistencial, na otimização e diversificação das formas de interação "eu-outro" e no "enriquecimento dos horizontes de saberes e fazeres" em saúde, numa perspectiva intersetorial e interdisciplinar ${ }^{(3)}$.

O trabalho e papel do enfermeiro na atenção básica frente às situações de bullying se estabelece como um desafio, seja na internalidade das unidades de saúde, no atendimento às crianças e aos adolescentes, seja, também, fora dos muros da unidade de saúde. Esse trabalho demanda ações referenciadas pela promoção da saúde, desenvolvimento de práticas educativas em saúde, identificação de sinais e sintomas de violência e consequentes necessidades de saúde, contribuição na formação de profissionais de educação e saúde, envolver alunos, educadores e famílias e valorização do protagonismo infantil e juvenil.

Destacamos que todo trabalho a ser desenvolvido na escola deve respeitá-la como espaço pedagógico e de formação, que congrega potencialidades para a promoção da saúde e também para a solução de problemas identificados. Portanto, as ações de educação em saúde nesse campo têm potencial para intervenção e prevenção do bullying, o qual se constitui em um problema também da área de enfermagem. Essas têm sido construídas a partir do estabelecimento de vínculos, saberes e dimensões complementares entre a ação de saúde, o pensar e o fazer cotidiano(4)

Para tanto, as práticas de educação em saúde a serem desenvolvidas pelo enfermeiro devem superar as práticas tradicionais presentes neste processo, ainda delineadas por concepções com foco no saber biomédico e em um agir 
individual, respondendo aos seus discursos, fortalecendo interesses políticos e econômicos em detrimento de um sujeito ativo, partícipe de processos $\operatorname{coletivos}^{(5-6)}$.

Em síntese, o modelo de atenção frente às situações de violência e bullying escolar, que a enfermagem, em especial os enfermeiros, devem construir, necessita de profissionais que ampliem seus conhecimentos e contribuam para produção do conhecimento científico na área da violência escolar. Nesse movimento devemos nos apropriar de novas teorias e práticas e, na escola, espaço possível de sua prática profissional, intersetorial e articulada, (re)construir um modelo de atenção à criança e ao adolescente que atue na prevenção e minimização do bullying. Assim, estaríamos atendendo ao desafio e compromisso técnico e ético de garantir a equidade, a proteção e uma melhor qualidade de vida na infância e adolescência.

\section{REFERÊNCIAS}

1. Mishima SM, Fortuna CM, Scochi CGS, Pereira MJB, Lima RAG, Matumoto S. Maria Cecília Puntel de Almeida: a trajetória de uma protagonista da enfermagem brasileira. Texto Contexto Enferm [Internet]. 2009 [acesso em: 30 set 2013];18(4):773-80. Disponível em: http://dx.doi.org/10.1590/S0104-07072009000400020.

2. Silva MJP. Nursing Science. Acta paul. enferm. [Internet]. 2012 [acesso em: 30 set 2013];25(4):i-ii. Disponível em: http://dx.doi.org/10.1590/S0103-21002012000400001.

3. Ayres JRCM. Cuidado e reconstrução das práticas de Saúde. Interface (Botucatu) [Internet]. 2004 [acesso em: 30 set 2013];8(4):7392. Disponivel em: http://dx.doi.org/10.1590/S1414-32832004000100005.

4. Vasconcelos EM. Educação popular e a atenção à saúde da família. 3a ed. São Paulo: Hucitec, 2006.

5. Colomé JS, Oliveira DLLC. Educação em saúde: por quem e para quem? A visão de estudantes de graduação em enfermagem. Texto Contexto Enferm [Internet]. 2012 [acesso em: 30 set 2013];21(1):177-84. Disponível em: http://dx.doi.org/10.1590/S010407072012000100020.

6. Renovato RD, Bagnato MHS. Práticas educativas em saúde e a constituição de sujeitos ativos. Texto Contexto Enferm [Internet]. 2010 [acesso em: 30 set 2013];19(3):554-62. Disponível em: http://dx.doi.org/10.1590/S0104-07072010000300018. 